\title{
Microbiological assessment of suya (sliced roasted beef) in Ado-Ekiti Metropolis, Ekiti State, Nigeria
}

\begin{abstract}
In an attempt to evaluate the safety in consumption of suya within the people of AdoEkiti, Ekiti- State, Nigeria, 20 samples of suya were collected from 10 different suya spots in Ado Ekiti. The total bacteria counts varies in each sample, in which suya sample collected at Atikankan area has the highest value of bacteria count of $2.85 \times 10^{5} \mathrm{CFU} / \mathrm{ml}$. The least bacteria count was recorded in sample $\mathrm{F}$ collected from Basiri area of AdoEkiti with $9.8 \times 10^{4} \mathrm{CFU} / \mathrm{ml}$. On the other hand, there is no coliform growth in the other plates. A total number of 20 bacteria were isolated from the suya samples. Five different bacteria genera were identified. The bacteria isolated were Escherichia coli, Enterobacter spp, Streptococcus spp., Staphylococcus aureus and Bacillus spp. Staphylococcus aureus is the most occurring bacteria isolated with percentage distribution of $13(65 \%)$, followed by Streptococcus spp with 3(15\%) and Bacillus spp. has 2(10\%). Escherichia coli and Enterobacter spp has the lowest number of occurrence with 1(5\%) respectively. The antibiotic susceptibility test reveals $25 \%$ of the bacteria were resistant to ciprofloxacin, $100 \%$ were resistant to Retafumurin and Cefotaxime respectively. $10 \%$ were resistant to levefloxacin and $50 \%$ were resistant to norfloxacin.
\end{abstract}

Volume 2 Issue 3 - 2017

\author{
Falegan CR',Akoja SO,' Oyarekua MA² \\ 'Department of Microbiology, Ekiti State University, Nigeria \\ ${ }^{2}$ Department of Microbiology, Federal University Oye Ekiti, \\ Nigeria
}

Correspondence: Akoja SO, Department of Microbiology Ekiti State University, Nigeria, Tel 08033850542 , Email faleganchristopherrotimi@gmail.com Received: November II, 2017 | Published: December 13,
2017

\section{Introduction}

Suya is a spicy, traditional stick meat product that is commonly produced by the Hausas in Northern Nigeria from beef. ${ }^{1}$ Where rearing of cattle are an important pre-occupation and major source of livelihood for the people. ${ }^{2}$ This leads to the production of ready -to-eat beef products such as suya, kilishi, balangu and kundi. suya is however the most popular as its consumption has extended to other part of the country. ${ }^{3}$ Suya is a popular, traditionally processed, ready to eat Nigerian meat product, which may be served or sold along the streets, in club houses, at picnics, parties, restaurants and within institutions. It is a mass consumer fast food. Its preparation and sales along the streets are usually not done under strict hygienic condition because they are still done locally with crude tools. Traditionally, processed meat products were produced and consumed in different countries throughout the world. ${ }^{5}$ Meat is a highly perishable food product, just like milk as described by Falegan, et al., ${ }^{6}$ which unless correctly stored, processed, packaged and distributed may spoil quickly and become hazardous to consumers due to microbial growth. ${ }^{6}$ Potential for microbial contamination is influenced by the condition prior to slaughter, abattoir practices, extent of handling and subsequent storage conditions. ${ }^{7}$ All raw meats can have some level of microbial contamination present and cannot be expected to be otherwise without further processing. ${ }^{8}$ Depending on the species and whether they are present, pathogen such as Listeria monocytogenes, Salmonella spp. and E. coli $0157: \mathrm{H} 7$ can grow and cause illness by the ingestion of the bacterial cells themselves or from toxins that they produce. The presence of pathogens in the food supply in low numbers is undesirable and is considered a major cause of gastrointestinal disease world-wide. ${ }^{9}$ Within the meat industry, assurance of meat safety and quality are of paramount importance. As the industry develops new technologies to produce higher quality and diverse meat products for increasingly competitive markets, systems must be designed to allow safeguards to be implemented into processing procedures. Traditional approaches to meat safety and quality have relied heavily on regulatory inspection and sampling regimes. However, these systems cannot guarantee total consumer protection unless $100 \%$ inspection and sampling are employed. In the meat industry, this level of inspection is impractical for various economic and logistic reasons..$^{10}$ Effective intervention to reduce contamination of beef begins with determining potential sources of contamination. Tissues under the hide of healthy cattle are usually sterile, ${ }^{11}$ consequently, tissues become contaminated during the slaughtering process. Sources of Meat contamination during slaughter maybe classified as those associated with the animal, processing practices, Abattoir facilities and employees. The extent to which Potential contamination sources become hazardous to public health depends on management and unpredictable events or factors. Even in the best managed slaughter facilities, Contamination may still occur. Fortunately, most bacterial Colonies which have been isolated from beef have been non-pathogenic, although human pathogens such as Salmonella, Campylobacter and Listeria have been isolated. ${ }^{12}$ Because of the high rate of consumption of suya, there is a need for microbiological analysis of the suya products in other to evaluate the microbial contamination of the samples and even to avoid infection from it consumption, although meat from freshly slaughtered, healthy animals is supposed to have no, or very low microbial populations, laboratory evidence suggests that they could be contaminated to an unsafe level at the point of consumption. The fact that there are sporadic cases of gastroenteritis and symptoms of food infection after consumption of suya indicate the products indeed constitute a food safety risk. ${ }^{3}$ The objective of this study is to examine the microbial status of Suya sold in different places of Ado-Ekiti, Ekiti State, Nigeria. This research work therefore aimed to evaluate total bacterial count and coliform counts in different suya samples, identification and characterization of the isolated bacteria as well as determine the antibiotics resistance on the isolated bacteria. 


\section{Materials and methods}

\section{Sampling and sample collection}

A total of 20 samples were collected from 10 randomly selected Suya spots; two samples at different locations. The suya samples were wrapped in sterile wrapping papers and re-enforced by aluminum foil to avoid contamination en route to the laboratory for microbial examination. The spots where the suya samples were collected were: sample A (Adebayo area), sample B (Fajuyi Area), sample C (Ajilosun area), sample D (Odo-Ado area), sample E (Atikankan area), sample F (Basiri area), sample G (Oke-ila area), sample H (Ekute area), sample I (Dalimore area) and sample J (Oke-ureje area). The samples were kept in an ice box at $4{ }^{\circ} \mathrm{C}$ and transferred into the Ekiti State University Microbiology Laboratory, located along Iworoko road, Ado-Ekiti, South West, Nigeria.

\section{Microbiological analysis}

Pieces of suya from each sample were removed and mashed in a sterile laboratory type mortar and pestle into a paste. Ten percent of the stock solution was prepared by weighing $10 \mathrm{~g}$ into $100 \mathrm{ml}$ of sterile buffered saline, properly shaken and sieved before a twofold dilution was performed. Serial dilution was carried out from the stock solution to obtain 1:10 dilution from 6 test tubes, given a dilution of $10^{-1}, 10$ ${ }^{2}, 10^{-3}, 10^{-4}, 10^{-5}$ and $10^{-6}$ respectively. Pour plate was conducted by obtaining $1 \mathrm{ml}$ of an aliquot from each of the test tubes and pouring into sterile petri-dishes. It was allowed to settle and $15 \mathrm{ml}$ of liquid nutrient agar (total plate counts) and MacConkey agar (total coliforms counts) cooled at $45^{\circ} \mathrm{C}$ was poured and incubated at $37^{\circ} \mathrm{C}$ for $24 \mathrm{hrs} .{ }^{13}$
The plate viable counts were conducted as described by Barrow et al. ${ }^{14}$

\section{Identification of isolated organism}

Microorganisms growing on solid surfaces medium tend to form colonies with distinctive morphologies. The variation in bacterial colony morphology can be observed with the naked eye. This morphological variation includes shape, odour, elevation surface on agar media. Specific biochemical test were carried out to distinctively identify the isolates. The biochemical tests include gram staining, indole, catalase, coagulase, motility citrate and sugar fermentation of the method of Olutiola et al. ${ }^{15}$

\section{Results}

In the total bacteria counts, the count varies according to each of the sample, with suya sample collected at Atikankan area has the highest value of $2.85 \times 10^{5} \mathrm{CFU} / \mathrm{ML}$. The least bacteria count was recorded in sample $\mathrm{F}$ (Basiri sample) with $9.8 \times 10^{4} \mathrm{CFU} / \mathrm{ML}$. On the other hand, there is no plate count for coliforms with each plate show no growth as it was shown in (Table 1). The occurrence and percentage distribution of the isolated bacteria was presented in (Table 2). A total number of 20 bacteria were isolated from the suya samples. Five different bacteria genera were isolated. The bacteria isolated were Escherichia coli, Enterobacter spp, Streptococcus spp., Staphylococcus aureus and Bacillus spp. Staphylococcus aureus is the most occurrent bacteria isolated with percentage distribution of 13(65\%), follow by Streptococcus spp with 3(15\%) and Bacillus spp. has $2(10 \%)$. Escherichia coli and Enterobacter spp has the lowest number of occurrence with $1(5 \%)$ respectively.

Table I The total viable counts (tvc) in the suya samples analysed

\begin{tabular}{|c|c|c|c|c|c|c|}
\hline \multirow{2}{*}{ Sample } & \multirow{2}{*}{ Source } & \multicolumn{2}{|c|}{ Number of colonies } & \multirow[t]{2}{*}{ Mean } & \multirow{2}{*}{$\begin{array}{l}\text { Total bacterial counts } \\
\left.10^{5} \mathrm{CFU} / \mathrm{ml}\right)\end{array}$} & \multirow[t]{2}{*}{ Total coliforms counts (CFU/ml) } \\
\hline & & Sample I & Sample 2 & & & \\
\hline A & Adebayo & 63 & 78 & $|4|$ & $1.4 \mathrm{I}$ & NG \\
\hline B & Fajuyi & 65 & 67 & 132 & 1.32 & NG \\
\hline C & Ajilosun & 64 & 76 & 140 & 1.40 & NG \\
\hline D & Odo-ado & 64 & 57 & 121 & 1.21 & NG \\
\hline $\mathrm{E}$ & Atikankan & 105 & 80 & 285 & 2.85 & NG \\
\hline $\mathrm{F}$ & Basiri & 53 & 40 & 093 & 0.93 & NG \\
\hline G & Oke-ila & 96 & 110 & 206 & 2.06 & NG \\
\hline $\mathrm{H}$ & Ekute & 92 & 96 & 188 & 1.88 & NG \\
\hline I & Dalimo & 98 & 80 & 178 & 1.78 & NG \\
\hline$J$ & Oke-ireje & 80 & 75 & 155 & 1.55 & NG \\
\hline
\end{tabular}

Key: NG-No Growth, CFU/ml, Colony Forming Unit/Milliliter.

Table 2 Occurrence and percentage distribution of the isolated bacteria

\begin{tabular}{llll}
\hline S/N & Bacteria & Occurrence & Percentage (\%) \\
\hline I & Bacillus spp & 2 & 10 \\
2 & E. coli & 1 & 5 \\
3 & Enterobacter spp & I & 5 \\
4 & Staphylococcus aureus & 13 & 65 \\
5 & Streptococcus spp & 3 & 15 \\
& Total & 20 & 100 \\
\hline
\end{tabular}

(Table 3) shows the multiple percentages of antibiotics resistant and phenotype of resistance against each of the bacteria genera. For Staphylococcus aureus, $100 \%$ were resistant to Retafumurin and cefotaxime respectively. $38.5 \%$ was resistant to norfloxacin, $7.7 \%$ were resistant to ciprofloxacin and none were resistant to levefloxacin antibiotic.

For Streptococcus spp., $100 \%$ were resistant to retafumarin and cefotaxime respectively. Also, $33.3 \%$ were resistant to norfloxacin and none were resistant to levfloxacin and ciprofloxacin. For Enterobacter spp., $100 \%$ were resistant to retafumurin, ciprofloxacin, norfloxacin and cefotaxime respectively and none were resistant to 
levfloxacin. $100 \%$ of the Bacillus spp. isolated was resistant to all the five antibiotics used. Escherichia coli was $100 \%$ resistant to retafumurin, ciprofloxacin, norfloxacin and cefotaxime respectively, except for levefloxacin where none were resistant to it. Table 4 below shows the multiple antibiotics resistant pattern of the isolates. $45 \%$ of the bacteria were resistant to two antibiotics of RET-CTX.35\% were resistant to three antibiotics of RET-NOR-CTX. 5\% resistant to CIPRET-CTX, for four antibiotics, $5 \%$ were resistant to CIP-RET-NORCTX and to all the five antibiotics, $100 \%$ were resistant to CIP-RETLEV-NOR-CTX.

Table 3 Multiple antibiotics resistance and phenotype of resistance

\begin{tabular}{llllllll}
\hline Antibiotics & & & & & & & \\
\hline Isolates & No of isolates $\mathbf{n}(\%)$ & CIP & RET & LEV & NOR & CTX & Phenotype of resistance \\
\hline S. aureus & $\mathrm{I}(100)$ & $\mathrm{I}$ & $\mathrm{I}$ & - & 5 & 13 & CIP-RET-NOR-CTX \\
Streptococcus spp. & $3(100)$ & - & 3 & - & $\mathrm{I}$ & 3 & RET-NOR-CTX \\
Enterobacter spp & $\mathrm{I}(100)$ & $\mathrm{I}$ & $\mathrm{I}$ & - & $\mathrm{I}$ & $\mathrm{I}$ & CIP-RET-NOR-CTX \\
Bacillus spp & $2(100)$ & 2 & 2 & 2 & 2 & 2 & CIP-RET-LEV-NOR-CTX \\
E. coli & $\mathrm{I}(100)$ & $\mathrm{I}$ & $\mathrm{I}$ & - & $\mathrm{I}$ & $\mathrm{I}$ & CIP-RET-NOR-CTX \\
\hline
\end{tabular}

Table 4 Multiple antibiotics resistance pattern of the isolates $(\mathrm{N}=20)$.

\begin{tabular}{lllll}
\hline S/N & No of antibiotics & Antibiotics resistance pattern & No of isolates & \% resistance \\
\hline I & One & - & - & - \\
2 & Two & RET-CTX & 9 & 45 \\
3 & Three & RET-NOR-CTX & 7 & 35 \\
4 & Three & CIP-RET-CTX & 1 & 5 \\
5 & Four & CIP-RET-NOR-CTX & 1 & 5 \\
6 & Five & CIP-RET-LEV-NOR-CTX & 2 & 10 \\
& Total & & 20 & 19 \\
\hline
\end{tabular}

Key: CIP, ciprofloxacin; RET. Retafumuarin; LEV, levfloxacin; NOR, norfloxacin and CTX, cefotaxime.

\section{Discussion}

Suya which is a traditional meat product gotten from beef hung on stick and spiced with peanut cake, salt, vegetable oil and other flavours followed by roasting around a glowing charcoal fire were analysed microbiologically. In the total bacteria counts, the count varies according to each of the sample, with suya sample collected at Atikankan area has the highest value of $2.85 \times 10^{5} \mathrm{CFU} / \mathrm{ml}$. the least bacteria count was recorded at sample F (Basiri sample) with $9.8 \times 10^{4} \mathrm{CFU} / \mathrm{ml}$. On the other hand, there is no plate count for coliforms with each plate show no growth as was shown in (Table 1). The observed total plate count in "Suya" samples analysed, were in line with reports by Eke et al. ${ }^{16}$ where the total viable count obtained ranged from $1.0 \times 10^{3}-4.8 \times 10^{3}$ and Egbebi and Seidu, ${ }^{17}$ that "Suya processed in Ekpoma (Edo State of Nigeria) and Ado/Akure (South West Nigeria) respectively, have microbial contaminations. Also, this work is in agreements with the reports by Edema et al. ${ }^{2}$ and Ologhobo et al. ${ }^{18}$ on the microbial hazards of poorly processed "Suya", as Uzeh et al. ${ }^{19}$ had earlier opined that the incidence of bacteria in "Suya" products in Nigeria, is of public health concern. A total number of 20 bacteria were isolated from the suya samples. Five different bacteria genera were isolated. The bacteria isolated were Escherichia coli, Enterobacter spp., Streptococcus spp., Staphylococcus aureus and Bacillus spp., Staphylococcus aureus is the most occurrence bacteria isolated with percentage distribution of 13(65\%), follow by Streptococcus spp with 3(15\%) and Bacillus spp. has $2(10 \%)$. Escherichia coli and Enterobacter spp has the lowest number of occurrence with $1(5 \%)$ respectively as was presented in Table 2. These findings are related to the work of Eke et al. ${ }^{16}$ were
6 bacteria genera were isolated. The presence of Staphylococcus aureus in the suya samples reveals that contamination can be from the hands of the sellers as since it is commonly found on hands, skin, clothing, the utensils, air, ${ }^{20,21}$ and even from the ingredients like the spices, because according to Frazier \& Westhoff ${ }^{22}$ spices may even serve as a source. In fact, most of those involved in the processing and sale of Suya, are usually illiterates without formal training in food preparation, which is necessary in the hygienic handling of foods)..$^{23}$ For the isolation of Enterobacter spp., E. coli and Bacillus spp. in the suya sample reveals that there is relatively lack of personal hygiene amongst the sellers of Suya, since humans are the largest source of food contaminants. ${ }^{24}$ Although coliforms count were not recorded in this study, it remains however, a cause for concern, considering the established limits in the Public Health Laboratory Service guidelines for bacteriological quality of ready-to-eat food samples at the point of sale. ${ }^{25}$ This was with accordance with the findings by Shamsuddeen and Ameh, ${ }^{26}$ who reported a high incidence of coagulase positive Staphylococci and E. coli in Kilishi (a type of Suya product) from Kano metropolis. Since E. coli and Enterobacter spp were isolated from the Suya samples examined and the presence of Bacillus spp. rendered the samples unsatisfactory according PHLS. ${ }^{25}$ Also, the level of these organisms in food has been described as an index of food hygiene. ${ }^{27}$ The antibioticsprofile reveals that, $25 \%$ of the bacteria were resistant to ciprofloxacin, $100 \%$ were resistant to retafumurin and cefotaxime respectively. $10 \%$ were resistant to levefloxacin and $50 \%$ were resistant to norfloxacin as was presented in (Table 3 ). This work is in accordance with the work of Uzeh et al. ${ }^{20}$ where bacteria isolated were tested against Ciprofloxacin, Ofloxacin, Erythromycin, Gentamycin and Streptomycin. The multiple percentages of antibiotics 
resistant and phenotype of resistance against each of the bacteria genera were shown in (Table 4). For Staphylococcus aureus, 100\% were resistant to retafumurin and cefotaxime respectively. $38.5 \%$ was resistant to norfloxacin, $7.7 \%$ were resistant to ciprofloxacin and none was resistant to levefloxacin antibiotic. For Streptococcus spp., 100\% were resistant to retafumurin and cefotaxime respectively. $33.3 \%$ were resistant to norfloxacin and none was resistant to levfloxacin and ciprofloxacin. For Enterobacter spp., 100\% were resistant to retafumurin, ciprofloxacin, norfloxacin and cefotaxime respectively and none were resistant to levfloxacin. $100 \%$ of the Bacillus spp. isolated was resistant to all the five antibiotics used. And for Escherichia coli, $100 \%$ were resistant to retafumurin, ciprofloxacin, norfloxacin and cefotaxime respectively, except for levefloxacin where none were resistant to it.

\section{Conclusion}

This study has shown that suya is prepared and sold under grossly unhygienic and unsafe conditions, thereby constituting a food safety risk. The results also buttressed the need to educate suya vendors on personal sanitation practices during handling products, also to make them understand the safety hazards associated with the food. The process and the use of appropriate controls so that any identified hazards is prevented, eliminated or reduced to the acceptable levels must be put in place. There is also a need for monitoring of these nutrition products by educating processors and consumers on good sanitary practices during processing displaying and sale of the products and the possible danger of contaminated products.

\section{Acknowledgements}

None.

\section{Conflict of interest}

The author declares no conflict of interest.

\section{References}

1. Alonge DO, Hiko AA. Traditional methods of meat preservation in Nigeria. West Afr Farm Fd Proc. 1981. p. 19-21.

2. Edema MA, Osho AT, Diala CI. Evaluation of Microbial Hazards associated with the processing of Suya (a grilled meat product). Scientific Resources and Essays. 2008;3(12):621-626.

3. Inyang $\mathrm{CU}$, Igyor MA, Uma EN. Bacterial quality of a smoked meat product (Suya). Nigerian Food Journal. 2005;23(1):239-242.

4. Igene JO, Mohammed ID. Consumers attitudes towards 'suya' meat product. Ann Borno. 2008. 1 p.

5. Vilar I, García Fontán MC, Prieto B, et al. A survey on themicrobiological changes during the manufacture of dry-cured lacon, a Spanish traditional meat product. J Appl Microbiol. 2000;89:1018-1026.

6. Falegan CR, Oluwaniyi TT. Microbial composition, Antibiotic sensitivity and proximate composition of popular imported powdered infant milk formulars sold in Ado-Ekiti, Nigeria. European/American journal. 2015;1(5):10-24.

7. Jackson TC, Hardin MD, Acuff GR. Heat resistance of Escherichia coli 0157:H7: in a nutrient medium and in ground beef patties as influenced by storage and holding temperature. Food Prot. 1997;59(3):230-237.
8. Davies A. Meat microbiology. In: Introduction to meat product manufacture, UK: Leatherhead food research association; 1992.

9. Buchanan RL, Whiting RC. Processed meats as a Arrhenius model and the square root model for predicting microbial environment. Food Technol. 1986;40:134-138.

10. Armitage NH. Use of predictive microbiology in meat hygiene regulatory activity. Int J Food Microbiol. 1997;36(2-3):103-109.

11. Anderson DC. Use of cereal residues in beef cattle production systems. Journal of Animal Science. 2012;46(3):849-861.

12. Dickson JS, Anderson ME. Microbiological decontamination of food animal carcasses by washing and sanitizing systems: A review. Journal Food Protection. 2012;55(2):133-140.

13. Nester EW, Aderson DG, Roberts CE, et al. Dynamic of bacterial growth in Microbiology. A Human perspective. 2nd ed. New York: McGraw Hill; 1998. p. 86-92.

14. Barrows A, Hauster WJ, Herrman K, et al. Mannual of Clinical Microbiology. 5th ed. Washington: 1991.

15. Olutiola PO, Famurewa O, Somntag HS. Bacteriologica determination of bacteria. Bolabary Publication. 1994. p. 101-111.

16. Eke SO, Irabor JI, Okoye M, et al. The microbial status of commercial 'suya' meat products in Ekpoma, Edo, Nigeria. International Journal of Community Research. 2013;2(1):18-21.

17. Egbebi AO, Seidu KT. Microbiological evaluation of Suya (dried smoked meat) sold in Ado and Akure, South West Nigeria. European Journal of Experimental Biology. 2011;1(4):1-5.

18. Ologhobo AD, Omojola AB, Ofongo ST, et al. Safety of street vended meat products - chicken and beef suya. African Journal of Biotechnology. 2010;9(26):4091-4095.

19. Uzeh RE, Ohenhen RE, Adeniji OO. Bacteria contamination of Tsire-suya, a Nigerian meat product. Pakistan Journal of Nutrition. 2006;5(5):458-460.

20. Gilbert U, Harrison A. Occurrence of enterotoxin producing staphylococcus aureus in meat market in Nigeria. Journal of Food Infection 2011;56:25-35.

21. Bukar A, Yushau M, Adikwu EM. Incidence and identification of potential pathogens on hands of personel in some small scale food industries in Kano metropolis. Biological and Environmental Sciences Journal for the Tropics. 2009;6(4).

22. Frazier WC, Westthroff WC. Food microbiology. 3rd ed. New York USA: McGraw Hill Publishing Company Limited; 2006. p. 163-165.

23. FAO. Draft revised guidelines for the design of control measures $f$ or street-tended foods in Africa. Rome: FAO; 1999. p. 24-43.

24. Marriot N. Principles of food sanitation. New York: Springer-Verlag; 1985. p. $70-80$.

25. PHLS, Public Health Laboratory Service. Communicable Diseases and Public Health. 2000;3:3.

26. Shamsuddeen U, Ameh JB. Survey on the possible critical control points in kilishi (a traditional dried and grilled meat snack) produced in kano. International Journal of Bioscience. 2008;3(2):34-38.

27. Adesokan IA, Odetoyinbo BB, Olubamiwa AO. Biopreservative activity of lactic acid bacteria on Suya produced from poultry meat. Afr J Biotech. 2008;7(5):3799-3803. 